\title{
MOLECULAR DIAGNOSIS OF HUNTINGTON DISEASE IN BRAZILIAN PATIENTS
}

\author{
TEREZA C. LIMA E SILVA*, HELIANE GUERRA SERRA**, \\ CARMEN S. BERTUZZO***, ISCIA LOPES-CENDES**
}

\begin{abstract}
Huntington disease $(H D)$ is a progressive neurodegenerative disorder with autosomal dominant inheritance, characterized by choreiform movements and cognitive impairment. Onset of symptoms is around 40 years of age and progression to death occurs in approximately 10 to 15 years from the time of disease onset. $H D$ is associated with an unstable CAG repeat expansion at the 5' and of the IT15 gene. We have genotyped the CAG repeat in the IT15 gene in 44 Brazilian individuals (42 patients and 2 unaffected family members) belonging to 34 unrelated families thought to segregate $H D$. We found one expanded CAG allele in 32 individuals (76\%) belonging to 25 unrelated families. In these $H D$ patients, expanded alleles varied from 43 to $73 \mathrm{CAG}$ units and normal alleles varied from 18 to 26 CAGs. A significant negative correlation between age at onset of symptoms and size of the expanded CAG allele was found $(\mathrm{r}=0.6 ; \mathrm{p}=0.0001)$; however, the size of the expanded CAG repeat could explain only about $40 \%$ of the variability in age at onset $\left(r^{2}=0.4\right)$. In addition, we genotyped 25 unrelated control individuals (total of 50 alleles) and found normal CAG repeats varying from 16 to 33 units. The percentage of heterozigocity of the normal allele in the control population was $88 \%$. In conclusion, our results showed that not all patients with the "HD" phenotype carried the expansion at the IT15 gene. Furthermore, molecular diagnosis was possible in all individuals, since no alleles of intermediate size were found. Therefore, molecular confirmation of the clinical diagnosis in $H D$ should be sought in all suspected patients, making it possible for adequate genetic counseling.
\end{abstract}

KEY WORDS: neurodegenerative disorders, involuntary movements, molecular tests.

\section{Diagnóstico molecular da doença de Huntington em pacientes brasileiros}

RESUMO - A doença de Huntington $(H D)$ é afecção neurodegenerativa com padrão de herança autossômica dominante caracterizada por movimentos involuntários coreiformes e alterações cognitivas. O início dos sintomas ocorre em torno dos 40 de idade, progredindo até a morte em um período de aproximadamente 10 a 15 anos após o início da doença. A $H D$ está associada a uma expansão trinucleotídica CAG presente na porção 5' do gene IT15. Nós investigamos a repetição CAG no gene IT15 em 44 indivíduos brasileiros (42 pacientes e 2 membros não afetados de uma família) pertencentes a 34 famílias não relacionadas com diagnóstico provável de $H D$. Um alelo CAG expandido foi encontrado em 32 indivíduos (76\%) pertencentes a 25 famílias não relacionadas. Nos pacientes com a mutação $H D$, os alelos expandidos variaram de 43 a 73 unidades de repetição CAG e os alelos normais apresentaram variação de 18 a 26 CAGs. Correlação negativa significativa foi encontrada entre a idade de início dos sintomas e o tamanho da expansão trinucleotídica CAG ( $\mathrm{r}=0,6 ; \mathrm{p}=0,0001)$; no entanto, o tamanho da repetição CAG expandida foi capaz de explicar somente $40 \%$ da variação encontrada na idade de início da doença $\left(\mathrm{r}^{2}=0,4\right)$. Além disso, nós genotipamos um total de 25 indivíduos pertencentes a um grupo controle da população brasileira (total de 50 alelos), sendo que o alelo normal apresentou variação de 16 a 33 unidades de repetição CAG. A porcentagem de heterozigozidade do alelo normal na população brasileira controle foi $88 \%$. Em conclusão, nossos resultados mostraram que nem todos os pacientes com fenótipo " $H D$ " possuíam a expansão CAG no gene IT15. O diagnóstico molecular foi possível em todos os indivíduos analisados nesse estudo, não sendo encontrada em nossa amostra nenhum alelo de tamanho intermediário. Portanto, nós recomendamos que a confirmação molecular do diagnóstico na $H D$ deva ser realizada em todos os casos suspeitos, a fim de proporcionar subsídios para um aconselhamento genético adequado.

PALAVRAS-CHAVE: doenças neurodegenerativas, distúrbios do movimento, teste molecular.

Departamento de Genética Médica, Faculdade de Ciências Médicas Universidade Estadual de Campinas (UNICAMP): *B.Sc.; **M.D., PhD.; ***PhD. This study was supported in part by FAPESP (Fundação de Amparo à Pesquisa do Estado de São Paulo). Aceite: 25-outubro-1999.

Iscia Lopes Cendes, M.D., Ph.D. - Departamento de Genética Médica Faculdade de Ciências Médicas-UNICAMP - Caixa Postal 6111 - 13083-970 Campinas SP - Brasil. FAX 19788 8909. Email: icendes@obelix.unicamp.br 
Huntington disease $(H D)$ is a progressive adult-onset neurodegenerative disorder presenting an autosomal dominant inheritance ${ }^{1-3}$. Onset of symptoms occurs usually in the fourth decade of life; however, it may vary from 4 to 80 years of age ${ }^{1-3}$. Prevalence of the disease is variable according to ethnic background, in Caucasians of North America and Europe it is believed to affect between 5 to 10 in 100000 population $^{1-3}$. $H D$ is clinically characterized by involuntary choreiform movements, cognitive impairment, and personality disorder tending to depression, anger and temper outbursts ${ }^{2,3}$. Neuronal degeneration is seen in several regions of the central nervous system, but is more evident in the caudate and the putamen of the basal ganglia ${ }^{2-4}$.

The $H D$ gene was genetically linked to an anonymous DNA marker located in chromosome (ch) 4 p16.35. After a decade of research the gene causing the disease, the IT15 gene, was identified by positional cloning techniques ${ }^{6}$. The mutation causing $H D$ was characterized as the expansion of an unstable CAG trinucleotide repeat localized in the first exon of the IT15 gene ${ }^{6}$. Studies in a large number of individuals of different ethnic origins have shown that normal alleles carry 6 to 34 CAG units; whereas, $H D$ alleles have more than $40 \mathrm{CAG}$ units ${ }^{7-10}$. It has been demonstrated that both normal and expanded CAG tracts encode a polyglutamine stretch within the protein named huntingtin ${ }^{11,12}$. Huntingtin is a $350 \mathrm{kDa}$ cytoplasmatic protein, widely expressed which has unknown function ${ }^{13}$.

Unstable expansions of CAG tracts have been found in a growing number of autosomal dominant degenerative disorders, including Kennedy disease ${ }^{14}$ and six types of autosomal dominant spinocerebellar ataxias (SCAs): SCA1, SCA2, MJD/SCA3, SCA6, SCA7 and DRPLA ${ }^{15}$. The exact mechanism by which expansions of CAG repeats cause disease is not understood; however, evidence points to a mechanism involving gain of function by the genes involved ${ }^{16-18}$.

We have genotyped the CAG trinucleotide repeat in the IT15 gene in Brazilian patients and control subjects in order to: a) confirm the presumptive clinical diagnosis of $H D$ in our group of patients, b) compare the size range of the CAG repeat in the $H D$ and control population, and c) investigate the relationship between the size of the expanded CAG allele and age at onset of the disease.

\section{SUBJECTS}

This study was performed using DNA samples, obtained after informed consent, from 44 family members, including 42 clinically affected individuals belonging to 34 unrelated families, 16 males and 28 females. Forty-two of these individuals presented with dementia and /or involuntary movements and received the presumptive clinical diagnosis of $H D$. There were two unaffected individuals belonging to one family from which a patient was also available for genotyping. Ages at onset varied from 12 to 58 years, mean of 39 years. Families were ascertained in four University based clinical centers in the southern and southeastern regions of Brazil: São Paulo, Rio de Janeiro and Paraná. Ages at onset were based on information provided by the patient and/or a close relative. For determination of the frequency of the normal alleles we used 50 normal chromosomes identified in 25 unrelated control individuals of the Brazilian population. This project was approved by the Ethics Committee of the Faculdade de Ciências Médicas - UNICAMP.

\section{METHOD}

Genomic DNA was isolated from peripheral lymphocyte by standard methods ${ }^{19}$. PCR amplification of the CAG repeat in the $I T 15$ gene was performed with primers $H D 1$ and $H D 3^{6,20}$, which are adjacent to the CAG stretch $^{6,20,21}$ PCR reactions were performed in a total volume of $12.5 \mu$ l containing 100 ng of genomic DNA; 1.6 $\mathrm{mM}$ of each dNTP (dATP, dCTP, dGTP, dTTP ); 4 pmol of each primer; 5\% DMSO; 0.2 U Perfect Match (Stratagene ${ }^{\circledR}$ ) and 0.5 units Taq DNA polimerase. After an initial denaturation of $2 \mathrm{~min}$ at $95^{\circ} \mathrm{C}$ the amplification was accomplished in 30 cycles at the following temperatures: denaturing at $94^{\circ} \mathrm{C}$ for 1 min, annealing at $50^{\circ} \mathrm{C}$ for $1 \mathrm{~min}$, and extension at $72^{\circ} \mathrm{C}$ for $2 \mathrm{~min}$, followed by a final extension at $72{ }^{\circ} \mathrm{C}$ for $7 \mathrm{~min}$. PCR products were separated by electrophoreses through a $6 \%$ denaturing polyacrylamide gel. Gels were transferred into Hybond $\mathrm{N}+$ nylon membranes and hybridized with a $\alpha-{ }^{32} \mathrm{P} 3$ '-end labeled $(\mathrm{CAG})_{15}$ probe $^{22}$. Allele sizes were determined by comparing migration relative to a sequencing ladder (Fig 1). Alleles were considered normal when less than 35 CAGs and expanded when they contained more than $40 \mathrm{CAGs}^{23}$. 


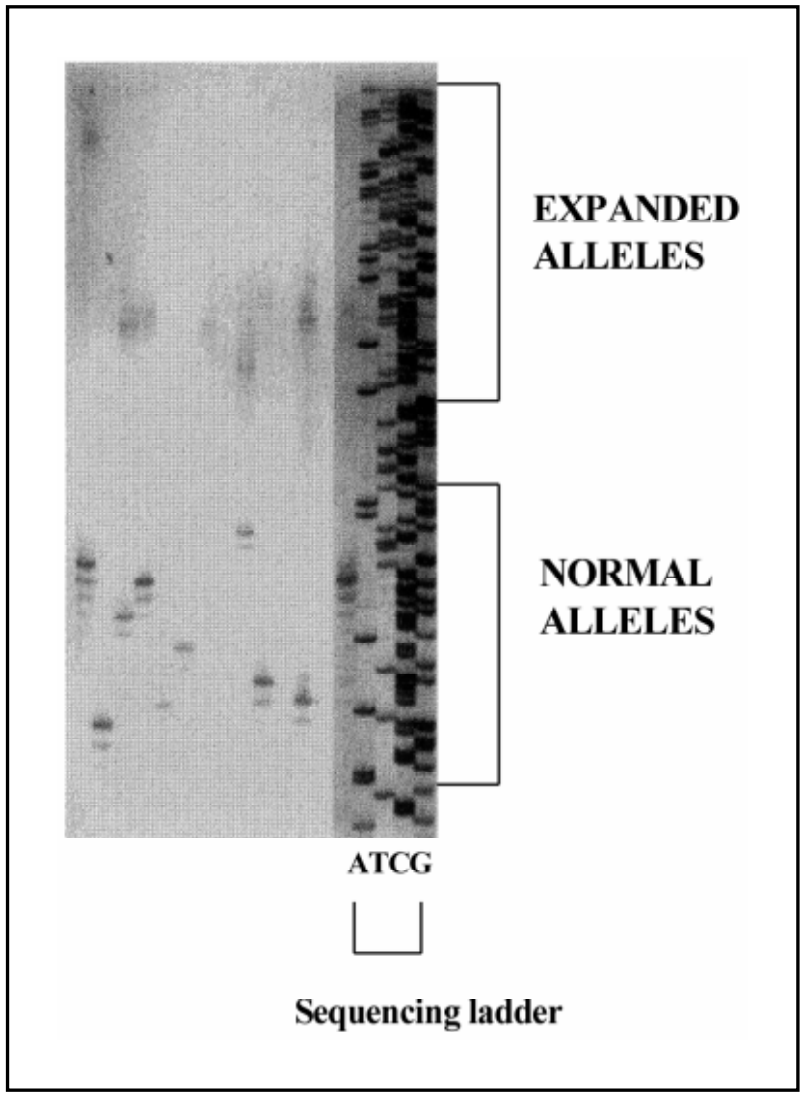

Fig 1. Analysis of PCR products containing the expanded $C A G$ repeat at the HD locus. Genomic DNA was amplified using primers HD1 e HD3 (ref.20). PCR products were analysed on $6 \%$ polyacrylamide gels. Allele sizes were determined by comparison with a sequencing ladder. Normal alleles (NA) had sizes varying from 19 to 26 CAG units and expanded alleles (EA) varied from 43 to 73 CAGs.

We used linear regression analysis to determine the association between repeat number in the $H D$ or normal alleles and age at onset. We assessed differences in repeat number among males, females, maternal and paternal transmissions by analysis of variance. All statistical analyses were accomplished by using the computer program SYSTAT ${ }^{24}$.

\section{RESULTS}

We identified 32 individuals, belonging to 25 families, with one expanded CAG allele at the IT15 gene. Two of these individuals were considered to be unaffected at the time of clinical evaluation, but had affected relatives who were also genotyped in our study. (Table). The frequency of the $H D$ mutation in our group of patients was 76\% (32/42). Expanded alleles varied from 43 to 73 CAG repeats (mean $=50.6 \mathrm{CAG}$ units) and normal alleles in $H D$ patients varied from 18 to $26 \mathrm{CAG}$ units (mean $=22$ CAGs) $($ Fig 2). There was no significant difference in the size of the expanded alleles between affected males (mean $=49.7)$ and affected females $($ mean $=52.3) ; \mathrm{p}=0.7$.

Autosomal dominant inheritance could be documented in all but 3 patients who had no family history of the disease. Transmission of the disease was paternal in 18 cases and maternal in 11 patients. There was no significant difference in the size of the expanded CAG repeat between patients with paternal (mean $=51.6 \mathrm{CAG}$ units) and maternal transmission $($ mean $=51.5 \mathrm{CAGs}) ; \mathrm{p}=1.00$.

The relationship between the CAG repeat length in the $H D$ allele of affected individuals and age at onset of the disease is shown in Figure 3A. A correlation coefficient of -0.6 was obtained $\left(\mathrm{r}^{2}=0.4 ; \mathrm{p}=0.0001\right)$, assuming a linear relationship between age at onset and repeat length in $H D$ chs. 
Table. Demographic data and molecular characteristics of 32 individuals segregating the HD mutation.

\begin{tabular}{|c|c|c|c|c|c|c|}
\hline ID & Family & Sex & Transmission & $\begin{array}{l}\text { Onset } \\
\text { (years) }\end{array}$ & $\begin{array}{l}\text { Expanded } \\
\text { Allele } \\
\text { (CAG units) }\end{array}$ & $\begin{array}{c}\text { Normal } \\
\text { Allele } \\
\text { (CAG units) }\end{array}$ \\
\hline 01 & HD1 & Male & Paternal & 38 & 52 & 20 \\
\hline 02 & HD1 & Male & Paternal & 40 & 49 & 19 \\
\hline 03 & HD2 & Female & Paternal & 26 & 55 & 19 \\
\hline 04 & HD3 & Male & Paternal & 40 & 47 & 22 \\
\hline 05 & HD3 & Male & Paternal & 26 & 48 & 23 \\
\hline 06 & HD4 & Female & Maternal & 12 & 72 & 22 \\
\hline 07 & HD5 & Male & Maternal & 58 & 43 & 22 \\
\hline 08 & HD6 & Female & Maternal & 26 & 52 & 26 \\
\hline 09 & HD7 & Female & Maternal & 37 & 47 & 22 \\
\hline 10 & HD8 & Female & Maternal & 32 & 48 & 18 \\
\hline 11 & HD10 & Male & Isolated & 22 & 45 & 21 \\
\hline 12 & HD11 & Female & Isolated & 20 & 54 & 26 \\
\hline 13 & HD12 & Male & Paternal & 25 & 45 & 20 \\
\hline 14 & HD13 & Female & Maternal & 29 & 52 & 20 \\
\hline 15 & HD14 & Male & Paternal & 38 & 46 & 26 \\
\hline 16 & HD14 & Male & Paternal & 39 & 50 & 26 \\
\hline 17 & HD20 & Male & Paternal & 32 & 53 & 26 \\
\hline 18 & HD22 & Male & Maternal & 30 & 54 & 20 \\
\hline 19 & $\mathrm{HD} 24$ & Female & Paternal & 53 & 50 & 25 \\
\hline 20 & $\mathrm{HD} 24$ & Female & Paternal & 34 & 49 & 25 \\
\hline 21 & HD25 & Female & Isolated & 54 & 43 & 20 \\
\hline 22 & HD26 & Female & Paternal & 53 & 46 & 25 \\
\hline 23 & HD26 & Female & Maternal & $\mathrm{U}^{*}$ & 46 & 25 \\
\hline 24 & HD26 & Female & Maternal & $\mathrm{U}^{*}$ & 49 & 26 \\
\hline 25 & HD27 & Male & Paternal & 42 & 52 & 20 \\
\hline 26 & HD28 & Female & Paternal & 50 & 50 & 19 \\
\hline 27 & HD29 & Female & Paternal & 40 & 53 & 20 \\
\hline 28 & HD29 & Male & Paternal & 14 & 54 & 20 \\
\hline 29 & HD30 & Female & Maternal & 34 & 58 & 25 \\
\hline 30 & HD31 & Male & Paternal & 25 & 58 & 20 \\
\hline 31 & HD33 & Female & Paternal & 16 & 73 & 20 \\
\hline 32 & HD34 & Female & Maternal & 32 & 46 & 20 \\
\hline
\end{tabular}

*U, unaffected individual 

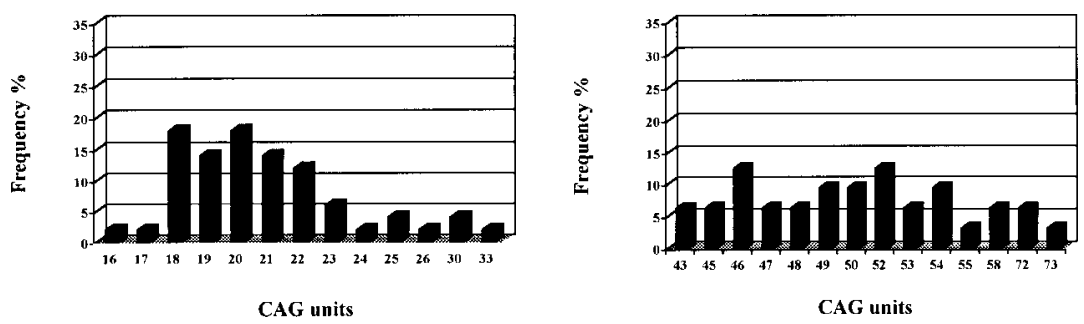

Fig 2. Frequency distribution of the CAG repeat sizes in controls and HD individuals. A) Distribution of 50 normal alleles genotyped in 25 unrelated control individuals of the Brazilian population. B) Distribution of 32 expanded alleles found in 25 unrelated Brazilian HD families.

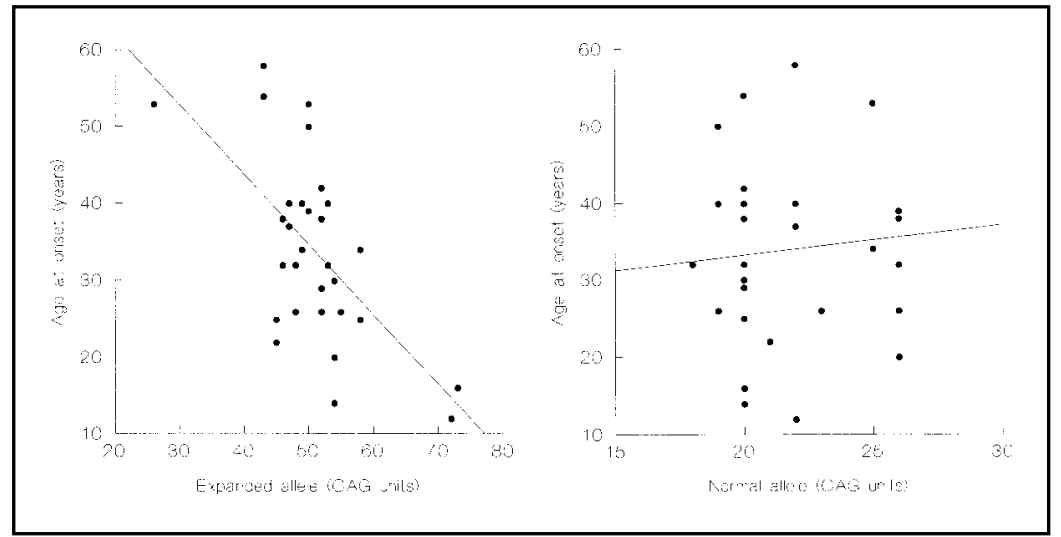

Fig 3. A) Correlation of CAG repeat length in $\mathrm{HD}$ chromosomes of 30 affected individuals with age at onset of the disease (Pearson correlation coefficient $\left.(r)=-0.6 ; r^{2}=0,4 ; p=0,0001\right) . B$ ) Absence of correlation between age at onset and CAG repeat length in the normal chromosomes of 30 affected individuals $\left(r=0.09 ; r^{2}=0.008 ; p=0.6\right)$.

No significant correlation was found between the normal CAG allele and age at onset $\left(r=0.09, r^{2}=\right.$ $0.008, \mathrm{p}=0.6$ ). (Figure 3B).

In the 25 individuals of the control group (total of 50 alleles) we found normal CAG repeats varying from 16 to $33 \mathrm{CAG}$ units; with $88 \%$ of control subjects being heterozygous for the CAG repeat in the IT15 gene. No expanded alleles were found in the control population.

\section{DISCUSSION}

With the cloning of the $H D$ gene in $1993^{6}$ and characterization of the causative mutation, an accurate diagnosis can now be performed, even in small families or single affected individuals. This results in a better estimate of the prevalence of $H D$, as well as provide more detailed clinical, pathological and molecular information that will improve our understanding of this disorder ${ }^{25}$. The same type of unstable expansion of a CAG tract has been found in other degenerative disorders and that the function of most genes involved in these diseases is still unknown ${ }^{15-17}$. However, recent evidence from protein studies and transgenic animal models suggest a toxic gain of function by the proteins containing an expanded glutamine tract ${ }^{11-13,18}$. Polyglutamine expansions in specific proteins, are one of the most intriguing pathological mechanisms causing adult-onset neurodegenerative disorders. While the normal gene product tolerate a wide variation in size of a polyglutamine tract, beyond a threshold the proteins 
acquire pathogenic properties ${ }^{16}$. The selective neuronal death that occur in all of these disorders, shows no correlation with the pattern of expression of the corresponding proteins. Since they are widely expressed in the central nervous system and peripheral tissue ${ }^{11-13}$. During the past two years research has moved towards studying the possible mechanisms by which expanded polyglutamine tracts cause neurodegeneration ${ }^{11,18}$. It is a very exciting new field of investigation, requiring molecular biology combined with cell biology tools; this will certainly provide important advances in the understanding of the mechanisms underlying neuronal death. The progress in basic research will in turn provide options for better treatment of patients suffering from these devastating disorders.

To our knowledge, this is the first study reporting molecular testing of $H D$ patients in the Brazilian population. Analysis of the CAG repeat in the IT15 gene in Brazilian families confirmed the presence of the expanded CAG repeat in $76 \%$ of patients with the presumptive diagnosis of $H D$. The size range of the expanded and normal alleles found in our study was similar to that reported in the literature ${ }^{6-10,23}$ and no intermediate alleles, between 35 and $40 \mathrm{CAGs}^{23,26,27}$, were found. Therefore, accurate molecular diagnosis was possible in all individuals. In addition, the high heterozygocity observed for the normal CAG tract in the Brazilian population ( $88 \%$ ) reduces the probability of finding individuals that are homozigous for the normal CAG allele. Individuals homozigous for the CAG allele in the normal range may be difficult to differentiate from failure to amplify an expanded allele in the PCR assay ${ }^{23}$.

Differences in the stability of the CAG tract according to sex of transmitting parent have been reported $^{7-10,28}$, with male transmissions being more unstable and with a tendency for further expansions of the abnormal CAG tract ${ }^{7,28}$. Although we could not document any transmission of the expanded CAG in this study, our results did not show any differences in the distribution of CAG alleles among groups according to gender of transmitting parent.

There are several well documented de novo mutations in sporadic $H D$ patients which have been reported in the literature ${ }^{7,29-31}$. We identified three patients with no family history of the disease who were found to have the $H D$ mutation. However, in all three instances clinical information on the parents could not be accurately obtained, since they either died at a very young age or were not available for examination. Therefore, it seems more likely that in these three families autosomal dominant transmission was not documented due to missing information. However, the possibility that in these patients the CAG repeat in the IT15 gene could have undergone a new mutation event cannot be completely excluded.

We found a significant correlation between age at onset of the disease and length of the expanded CAG tract. This indicates a tendency for age at onset to decrease as the CAG repeat length increases. Overall, $40 \%$ of variability in age at onset could be accounted for by the size of the CAG tract. However, our data (Table) together with reports in the literature ${ }^{6,32,33}$ suggest that any given expanded CAG repeat is associated with a broad range of onset ages, highlighting the importance of other factors in determining age at onset. The most frequent found expanded allele in our study was 52 CAG repeats, which was associated with ages at onset varying from 26 to 42 years. Therefore, predictions of age at onset based on expanded CAG repeat sizes should not be used as indicator of age at onset in individuals patients.

In conclusion, our results showed that not all patients with the " $H D$ " phenotype carried the expansion at the IT15 gene and that autosomal dominant inheritance may not be clearly documented in all $H D$ families. Therefore, molecular confirmation of the clinical diagnosis should be sought in all patients with suspected $H D$, even in apparently isolated cases. However, it is important to emphasize that a multidisciplinary, counseling and supportive group should always be available for patients undergoing molecular testing ${ }^{34-36}$.

Acknowledgments - We are grateful to all patients and their families. We would like to thank Drs:. M. Vianna, E. Quagliato, J.A. Maciel, W.Passos, H.A.G.Teive, P. Bertolluci, and P. Dalgalarondo for referring patients. 


\section{REFERENCES}

1. Harper PS. Huntington's disease. Major Problems in Neurology, vol 31. 2Ed, London: Saunders, 1991.

2. Hayden MR. Huntigton's chorea. New York: Springer-Verlag, 1981.

3. Koroshetz WJ, and Martin JB. Huntington's disease, In: Rosenberg RN, Prusiner SB, DiMauro S, Barchi RL (eds). The molecular and genetic basis of neurological disease. Boston: Butterworth-Heinemann, 1997:545-564.

4. Martin JB, Gusella JF. Huntington's disease: pathogenesis and management. N Engl J Med 1986;315:1267-1276.

5. Gusella JF, Wexler NS, Conneally PM, et al. A polymorphic DNA marker genetically linked to Huntington's disease. Nature 1983;306:234-238.

6. The Huntington's Disease Collaborative Research Group. A novel gene containing a trinucleotide repeat that is expanded end unstable on Huntington's disease chromosomes. Cell 1993;72:971-983.

7. De Rooji KE, De Konning Gans PAM, Skaastad MI, et al. Dynamic mutations in Dutch Huntington's disease patients: increased paternal repeat instability extending to within the normal size range. J Med Genet 1993;30:996-1002.

8. Zühlke C, Riess O, Schröder K, et al. Expansion of the (CAG)n repeat causing Huntington's disease in 352 patients of German origin. Hum Molec Genet 1993;2:1467-1469.

9. Novelletto A, Persichetti F, Sabbadini G, et al. Analysis of the trinucleotide repeat expansion in Italian families affected with Huntington disease. Hum Mol Genet 1994;3:93-98.

10. Barron LH, Warner JP, Porteus M, et al. A study of the Huntington's disease associated trinucleotide repeat in the Scottish population. J Med Genet 1993;30:1003-1007.

11. Huq AM, Hackam A, Graham RK, Wellington CL, Hayden MR. Molecular pathogenesis of Huntington's disease: biochemical studies of huntingtin. In:Well RD, Warren ST (eds). Genetic instability and hereditary neurological diseases, San Diego: Academic Press, 1998:325-354.

12. Trottier Y, Devys D, Imbert G, et al. Cellular localization of the Huntington's disease protein and discrimination of the normal and mutated form. Nat Genet 1995;10:104-110.

13. Sharp AH, Love SJ, Schilling G, et al. Widespread expression of Huntington's disease gene (IT15) protein product. Neuron 1995; $14: 1065-1074$

14. La Spada AR, Wilson EM, Lubahn DB, et al. Androgen receptor gene mutation in X-linked spinal and bulbar muscular atrophy. Nature 1991;352:77-79.

15. Zoghbi HY. The expanding world of ataxins. Nat Genet 1996;14:237-238.

16. Ross CA. When more is less: pathogenesis of glutamine repeat neurodegenerative diseases. Neuron 1995;15:493-496.

17. Koshy BT, Zoghbi HY. The CAG/polyglutamine tract diseases: gene products and molecular pathogenesis. Brain Pathol 1997;7:927-942.

18. de Rooij KE, De Konning Gans PAM, Losekoot M, et al. Ectopically expressed CAG repeats cause intranuclear inclusions and a progressive late onset neurological phenotype in the mouse. Cell 1997;91:753-763.

19. Sambrook J, Fritsch EF, Maniatis T. Molecular cloning: a laboratory manual. New York, Cold Spring Harbor Laboratory Press, 1989.

20. Warner JP, Barron LB ,Brck DJH. A newe polymerase chain reaction (PCR) assay for the trinucleotide repeat that is unstable and expanded on Huntingyon's disease chromosomes. Molec Cell Probes 1993;7:235-239.

21. Rubinsztein DC, Leggo J, Barton DE, et al. Site of (CCG)n polymorphism in the HD gene. Nat Genet 1993;5:214-215.

22. Lopes-Cendes I, Teive HAG, Cardoso F, et al. Molecular characteristics of the Machado-Joseph disease mutation in 25 newly described Brazilian families. Braz J Genet 1997;20:717-724.

23. The American College of Medical Genetics/American Society of Human Genetics Huntington disease Genetic Testing Working Group. ACMG/ASHG statement. Laboratory guidelines for Huntington disease genetic testing.. Am J Hum Genet 1998;62:1243-1247.

24. Wilkinson L. SYSTAT: the system for statistics. Evanston, IL: SYSTAT, 1990.

25. Gasser T, Grabhadern K. Advances in the genetics of movement disorders: implications for molecular diagnosis. J Neurol Neurosurg Psquiatry 1997;244:341-348.

26. Rubinsztein, DC, Leggo, J, Coles R, et al. Phenotypic characterization of individuals with 30-40 CAG repeats in Huntington's disease $(H D)$ gene reveals $H D$ cases with 36 repeats and apparently normal elderly individuals with $36-39$ repeats. Am J Hum Genet 1996;59:16-22.

27. Goldberg YP, Kremer B, Andrew SE, et al. Molecular analysis of new mutations for Huntington's disease, intermediate alleles and sex of origin effects. Nat Genet 1993;5:174-179.

28. Trottier Y, Biancalana V and Mandel J-L. Instability of the CAG repeat in Huntington's disease: relation to parental transmission and age at onset. J Med Genet 1993;31:377-382.

29. Myers RH, MacDonald ME, Koroshetz WJ, et al. De novo expansion of a (CAG)n repeat in sporadic Huntington's disease. Nat Genet 1993;5:168-173.

30. Davis MB, Bateman D, Quinn NP, Marsden CD, Harding A. Mutation analysis in patients with possible but apparently sporadic Huntington's disease. Lancet 1994;344:714-717.

31. Dürr A, Dodé C, Hahn V, et al. Diagnosis of "sporadic" Huntington's disease. J Neurol Sci 1995;129:51-55.

32. Duyao MP, Ambrose CM, Myers RH, et al. Trinucleotide repeat length: instability and age of onset in Huntington disease. Nat Genet 1993;4:387-392.

33. Brinkman RR, Mezei MM, Theilmann J, et al. The likelihood of being affected with Huntington disease by a particular age, for a specific CAG size. Am J Hum Genet 1997;60:1202-1210.

34. World Federation of Neurology Research Committee Group on Huntington's Disease. Ethical issues policy statement on huntington's disease molecular genetics predictive test. J Med Genet 1990;27:34-38.

35. The American Academy of Neurology. Consensus statement: guidelines for the molecular genetics predictive testing in Huntington's disease. Neurology 1994;44:1533-1536.

36. Benjamin CM, Adam S, Wiggins S, et al. Proceed with care: direct predictive testing for Huntington disease. Am J Hum Genet 1994;55:606-617. 